\title{
Comprehensive Examination of Therapies for Pain in Parkinson's Disease: A Systematic Review and Meta-Analysis
}

\author{
Abdul Rehman Qureshia Abdul Qayyum Rana ${ }^{a}$ Suleiman H. Malik ${ }^{a}$ \\ Syed Fayyaz H. Rizvi ${ }^{a}$ Shakib Akhter ${ }^{b}$ Christopher Vannabouathong ${ }^{b}$ \\ Zainab Sarfraz ${ }^{c}$ Ruqqiyah Rana ${ }^{a}$ \\ a Parkinson's Clinic of Eastern Toronto, Toronto, ON, Canada; ${ }^{b}$ McMaster University, Department of Health, Evidence \\ and Impact, Hamilton, ON, Canada; ' University of Health Sciences, Khayaban-e-Jamia Punjab, Lahore, Pakistan
}

\section{Keywords}

Parkinson's disease · Pain therapy · Meta-analysis

\section{Abstract}

Pain in Parkinson's disease (PD) is a debilitating symptom with a prevalence of $68 \%$, yet is untreated $50 \%$ of the time. What is unclear, however, is which treatment is optimal for minimizing pain severity in PD. Thus, the objective of this systematic review and meta-analysis was to investigate the efficacy of a variety of novel, complimentary, and conventional treatments for pain in PD and elucidate which therapy is the most effective. A systematic search was performed using MEDLINE, PsycINFO, Embase, CINAHL, and CENTRAL databases. To identify additional articles, manual searches of reference lists of included trials were also searched. Major neurology conference proceedings occurring between January 2014 and February 2018 were also searched to identify unpublished studies that may be potentially eligible. Twenty-five randomized controlled trials that encompassed medical, surgical, and complementary therapies met our inclusion criteria and exhibited moderate quality evidence. Two reviewers conducted assessments for study eligibility, risk of bias, data extraction, and quality of evidence rating. A conservative random-effects model was used to pool effect estimates of pain severity. The greatest reductions in pain were found with safinamide (Standardized mean difference = $-4.83,95 \% \mathrm{Cl}[-5.07$ to -4.59$], p<0.0001)$, followed by cannabinoids and opioids, multidisciplinary team care, catechol-O-methyltransferase inhibitors, and electrical and Chinese therapies. Moderate effects in reducing pain were in pardoprunox and surgery, while the weakest effects were in dopaminergic agonists and miscellaneous therapies. Safinamide is an important adjunct to standard parkinsonian medication for alleviating pain in PD. @ 2018 S. Karger AG, Basel

\section{Introduction}

Parkinson's disease (PD) is a progressive neurodegenerative condition with a prevalence of $0.3 \%$ of the entire population (or $1 \%$ for people above the age of 65 ), and continues to increase alarmingly with associated eco-
(C) 2018 S. Karger AG, Basel

E-Mail karger@karger.com

www.karger.com/ned
Abdul Rehman Quresh

Senior Clinical Research Coordinator

Parkinson's Clinic of Eastern Toronto

1-2060 Ellesmere Road, Toronto, ON M1H 2V6 (Canada)

E-Mail arq6@me.com 
nomic and social burden [1-3]. PD is often associated with muscle rigidity, tremors, and cognitive decline particularly in patients over 40 years of age. Pain is an extremely common non-motor symptom that is prevalent among $68-95 \%$ of PD patients [4-7]. Pain in PD has a significant impact on quality of life, evidenced by its association with higher scores of both depression and anxiety in these patients [8]. Despite the high rates of pain prevalence, between 25 and $50 \%$ of PD patients are receiving no treatment for their pain [4-6]. A notable concern in PD is the experience and severity of pain across various patient populations [9].

Pain in PD is attributable to a primary or secondary cause. Primary causes are associated with early morning dystonia or motor fluctuations compared to secondary causes that are associated with musculoskeletal pain [10]. Although various treatments exist for PD, it is unclear as to which is most effective in alleviating pain in PD. We performed a meta-analysis of randomized controlled trials (RCTs) to determine the effect of conventional, complementary or experimental therapies on pain severity in PD.

\section{Methods}

The reporting of this study is in accordance to the Preferred Reporting Items for Systematic Reviews and Meta-Analyses statement [11], and the protocols for reviews detailed in the Cochrane Handbook for Systematic Reviews of Interventions [12] (Appen$\operatorname{dix} 1)$.

\section{Identification of Studies}

A systematic search was performed using MEDLINE, PsycINFO, Embase, CINAHL, and CENTRAL from the inception of the databases to February 2, 2018. To increase the sensitivity of the search, we used MeSH and EMTREE headings in various combinations and supplemented with free text (Appendix 2). Reference lists of included trials were also searched to identify additional articles. Major neurology conference proceedings occurring between January 2014 and February 2018 were also searched to identify unpublished studies that may be potentially eligible.

\section{Assessment of Eligibility}

Two authors independently screened titles and abstracts which were followed by a full-text screening to determine eligibility of clinical trials. All disagreements were resolved through consensus and via arbitration by a senior author.

All studies meeting the following criteria were included:

(1) RCTs only.

(2) Trials assessing a continuous measure of pain severity.

(3) Adult patients (age $\geq 18$ ) with idiopathic PD.

No restrictions were made for language, publication date, presence of absence of co-interventions, or length of follow-up.
Assessment of Risk of Bias

The risk of bias tool in Review Manager (RevMan) by the Cochrane Collaboration was used by 2 reviewers (A.R.Q. and S.M.) to independently perform a risk of bias assessment [12]. Study authors were contacted to resolve any concerns.

\section{Data Extraction}

The extracted data from available studies included first author's last name, publication year, RCT design, scale used to calculate pain severity, therapeutic intervention, funding source, and country. Furthermore, data for treatment and control groups were extracted in terms of sample size, age, gender, disease duration, and the amount of missing or lost data in terms of participants. In the event where important data was unclear or missing, we attempted to contact study authors to retrieve such information.

\section{Statistical Analyses}

Agreement of reviewers' assessment for study eligibility was calculated using Cohen's kappa coefficient ( $\kappa$ ), with $\kappa \geq 0.65$ being considered adequate [13]. The intraclass correlation coefficient was used to calculated reviewer agreement for the risk of bias assessment. A conservative random-effects model of DerSimonian and Laird [14] was used to pool effect estimates of pain severity using Prometa 3. Pain severity effect estimates relative to control were generated using the standardized mean difference (SMD) with $95 \%$ CIs. Negative values for pain severity represent pain reduction, while positive values represent pain augmentation. Publication bias was examined through funnel plots, as well as Egger's and Begg's tests for publication bias. All tests of significance were 2 -tailed, with a significance threshold set at $p=0.05$.

\section{Evaluation of Heterogeneity}

Heterogeneity was quantified using the $I^{2}$ statistic from the $\mathrm{X}^{2}$ test for heterogeneity. In accordance to the interpretation from the Cochrane Handbook, heterogeneity for $I^{2}$ values between 30 and $60 \%$ may be moderate, 50 and $90 \%$ may be substantial, while values between 75 and $100 \%$ may be considerable [12]. We hypothesized a priori that heterogeneity may be accounted for by treatment drug dosage, the particular procedure of therapy, and stage of the disease.

\section{Sensitivity Analysis}

The main analysis consisted of patients who successfully completed follow-up and were analyzed within the eligible trials. Participants with missing data were not included. To explore the effect of missing data, we conducted an a priori sensitivity analysis that used the participants enrolled as the sample sizes for all eligible trials, assuming that the pain severity scores for treatment and control groups remained the same. Furthermore, a second a priori sensitivity analysis included studies with less than 2 ratings of high-risk bias across any of the categories of the risk of bias assessment.

\section{GRADE Quality Assessment and Summary of Findings}

The GRADE quality assessment guidelines were used to analyze the quality of evidence for or against the use of treatments in PD for reducing pain [15]. Although RCTs produce the highest quality of evidence, we conducted a quality assessment, as they are still susceptible to bias, imprecision, inconsistency, and poor methodological construct. 


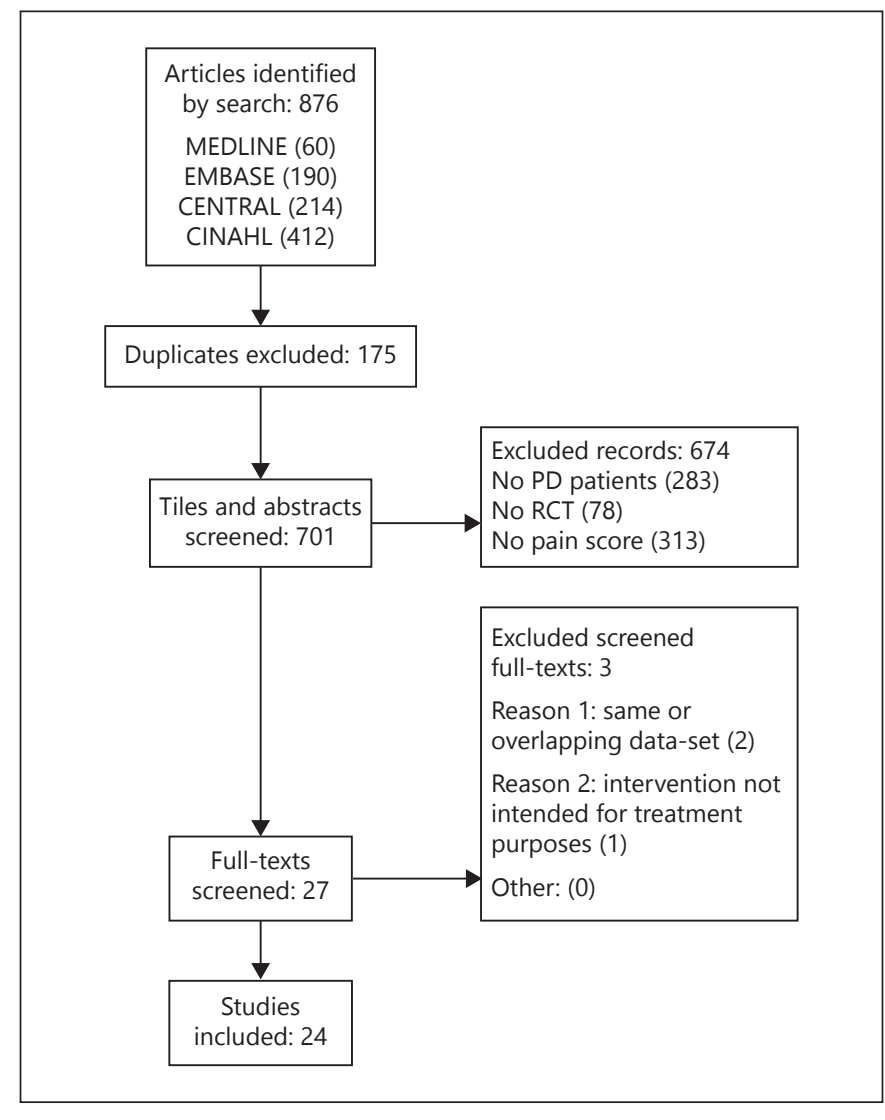

Fig. 1. PRISMA flow chart. A flowchart ultimately showing the included studies. PRISMA, preferred reporting items for systematic reviews and meta-analyses.

\section{Results}

\section{Eligible and Included Studies}

Out of 876 potentially eligible articles, 175 were duplicates and the remaining 701 titles and abstracts were screened. Subsequently, 27 full-texts were screened and 24 were ultimately eligible for our review (Fig. 1). One study pooled the results of 2 (RCTs [16]. Thus, 25 RCTs were included with a total of 1,744 patients undergoing a therapeutic intervention and 1,610 patients undergoing a control intervention. Agreement between the reviewers for study eligibility was moderately high $(\kappa=0.724,95 \%$ CI [0.479-0.969], $p<0.0001)$ and the agreement for risk of bias assessment was very high (intraclass correlation coefficient $=0.856,95 \%$ CI [0.714-0.927],$p<0.0001$ ).

\section{Study Characteristics}

The mean age of study participants was 66 years in the treatment and control groups. The proportion of male patients was $61 \%$ in the treatment group and $60 \%$ in the control group. Mean disease duration of PD was 7.9 (3.5) years and 7.2 (3.4) years in the treatment and control group respectively (Table 1, please see Appendix 3 for group-wise demographics).

The number of trials for each identifiable therapeutic intervention category was 3 for dopaminergic agonists [17-19], 2 for cannabinoids and opioids [20, 21], 3 for surgical methods [22-24], 4 for electrical or Chinese therapies [25-28], 2 for pardoprunox [29, 30], 2 for safinamide [16], 1 for catechol-O-methyltransferase (COMT) inhibitors [31], 1 for multidisciplinary team care [32], and 7 for miscellaneous therapies. Miscellaneous therapies included hydrotherapy [33, 34], massage therapy [35], gym training [36], mindfulness therapy [37], vibration therapy [38], and power yoga [39] (Table 1, with further intervention details in Appendix 4).

Pain severity was reported in 8 trials using the pain subscale of the Visual Analogue Scale (VAS-P) [17, 24, $26,27,29,30,33,35]$, in 8 using section 39 of the Parkinson's Disease Questionnaire-39 [16, 22, 23, 31, 32, 36, $37,39]$, in 4 using the Likert pain scale $[18,19,34,38]$, in 1 using the King Parkinson's Disease Pain Scale [21], in 1 using question 1.9 of the Movement Disorders Society - Unified Parkinson's Disease Rating Scale (MDSUPDRS Q1.9) [25], in 1 using the McGill Pain Scale [20], and in 1 trial using the Daily Pain Rating Sheet [28] (Table 1).

\section{Risk of Bias}

The risk of bias assessment through RevMan is summarized (Fig. 2). The funnel plot for pain severity was fairly symmetric (Fig. 3), with publication bias being statistically insignificant (Egger: $p=0.776$; Begg: $p=0.427$ ).

\section{Pain Severity}

The largest effects for pain severity reduction were found in safinamide (SMD $=-4.83, p<0.0001$ ), followed by cannabinoids and opioids (SMD $=-2.24, p<0.0001$; $\left.I^{2}=0.00 \%, p=0.363\right)$, multidisciplinary team care $(\mathrm{SMD}=$ $-2.01, p<0.0001)$, and COMT inhibitors (SMD $=-1.81$, $p<0.0001)$. Thereafter was a large effect from electrical and Chinese therapies with considerable heterogeneity $\left(\mathrm{SMD}=-0.98, p=0.020 ; I^{2}=86.9 \%, p<0.0001\right)$. Moderate sized effects on pain severity reduction were found for pardoprunox with insignificant heterogeneity $(\mathrm{SMD}=$ $-0.50, p=0.001 ; I^{2}=69.0 \%, p=0.073$ ), followed by surgery with insignificant heterogeneity $(\mathrm{SMD}=-0.42, p=$ $0.011 ; I^{2}=26.6 \%, p=0.256$ ). Small effects for pain severity reduction were found for dopaminergic agonists with insignificant heterogeneity $(\mathrm{SMD}=-0.27, p<0.0001$; 


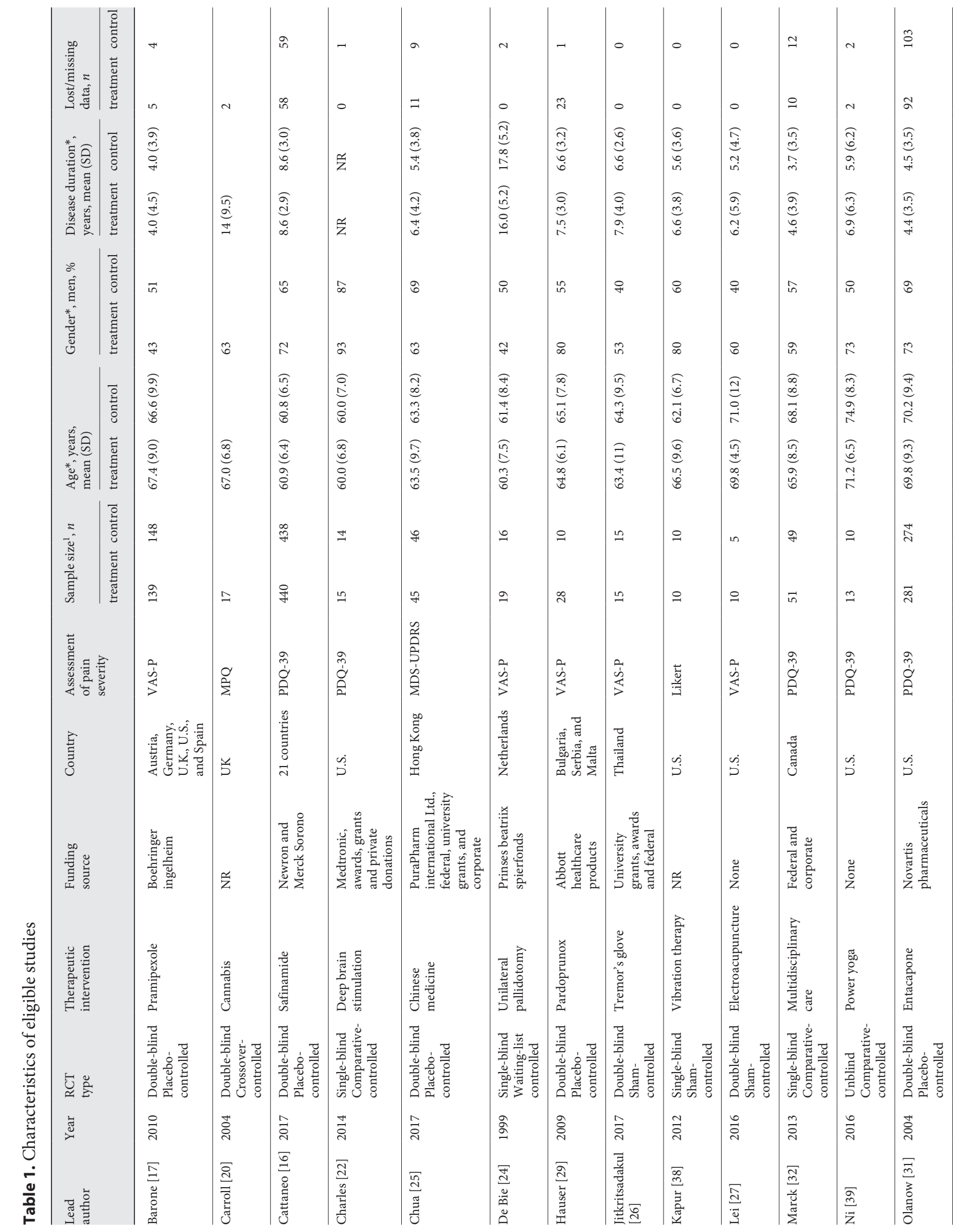




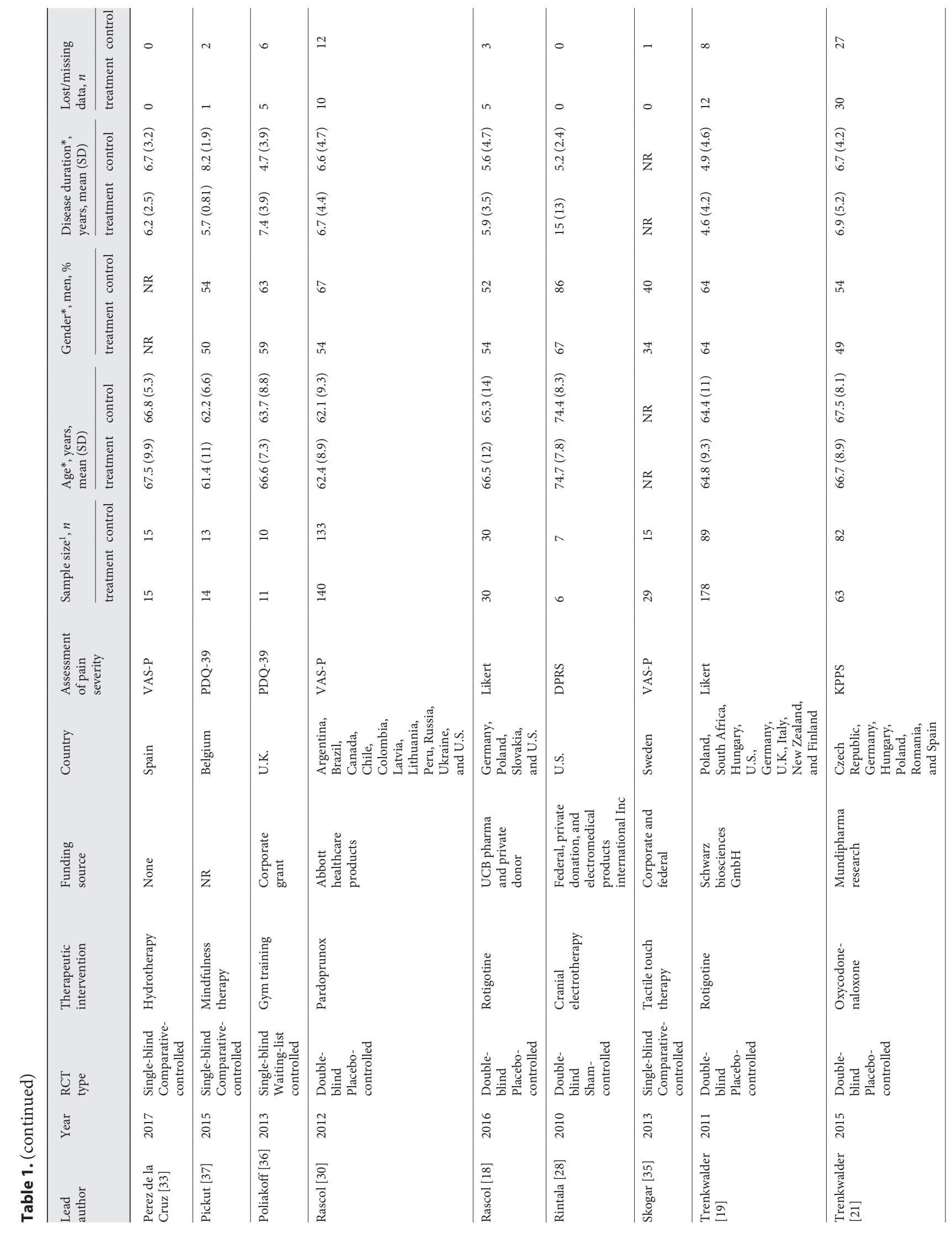




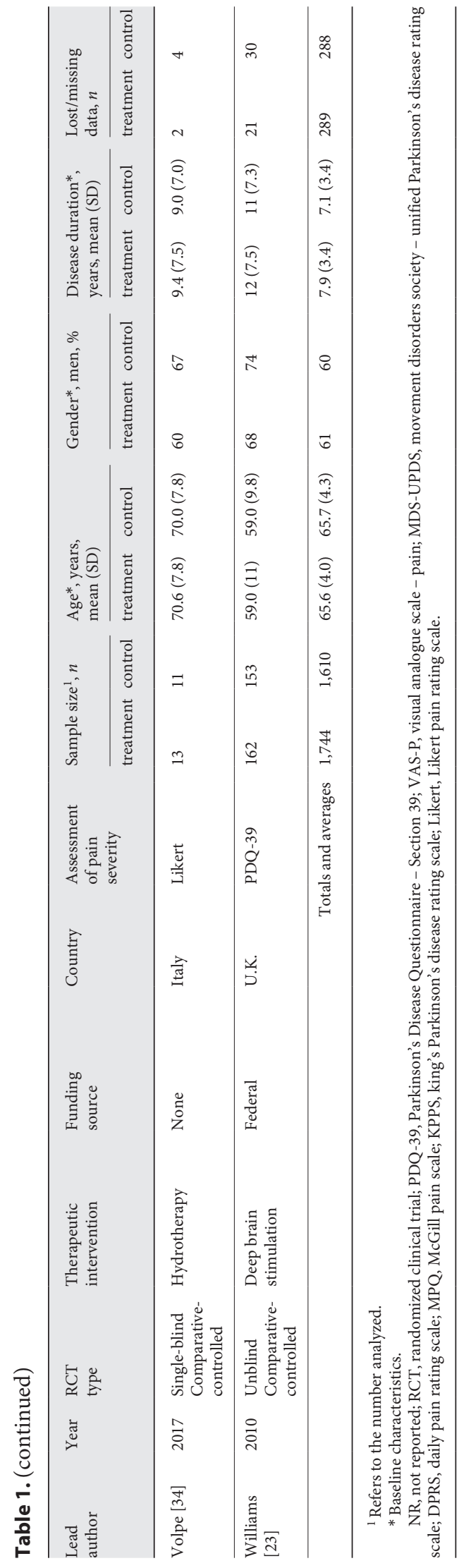

Comprehensive Examination of Therapies for Pain in Parkinson's Disease

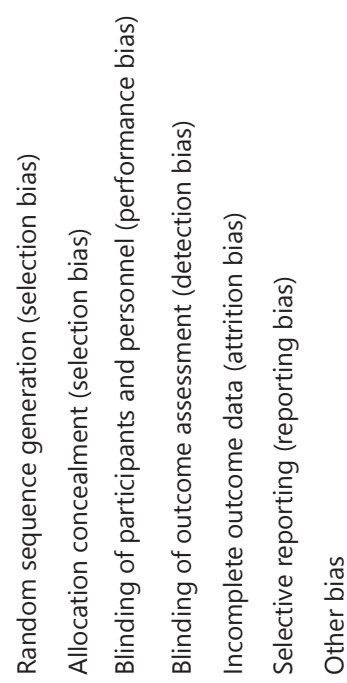

Barone, 2010

Carroll, 2004

Cattaneo, 2017

Charles, 2014

Chua, 2017

de Bie, 1999

Hauser, 2009

Jitkritsadakul, 201

Kapur, 2012

Lei, 2016

Marck, 2013

Ni, 201

Olanow, 2004

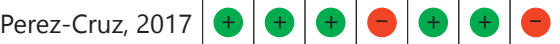

Pickut, 2015

Poliakoff, 2013

Rascol, 201

Rascol, 2016

Rintala, 2010

Skogar, 2013

Trenkwalder, 201

Trenkwalder, 2015

Volpe, 2017

Williams, 2010
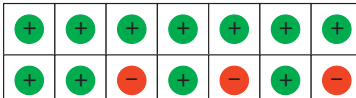

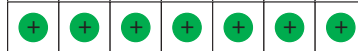

\begin{tabular}{|c|c|c|c|c|c|c|}
\hline & - & - & + & + & + & $\ddots$ \\
\hline
\end{tabular}

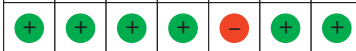

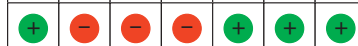

\begin{tabular}{|c|c|c|c|c|c|c|}
\hline+ & + & + & + & - & + & - \\
\hline
\end{tabular}

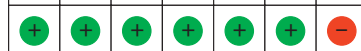

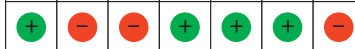

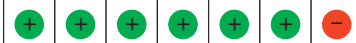

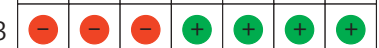

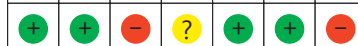

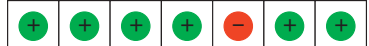

$+\odot \odot \odot \odot \odot$ ?

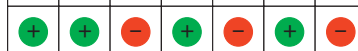

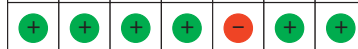

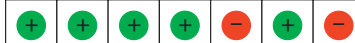

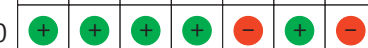

$+\odot$ ?

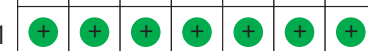

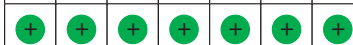

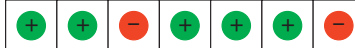

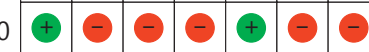

Fig. 2. Risk of bias assessment - a summative review of each risk of bias item for each included trial. "+" indicates low risk of bias, "-“ indicates high risk of bias, while "?" indicates that bias is unclear. 


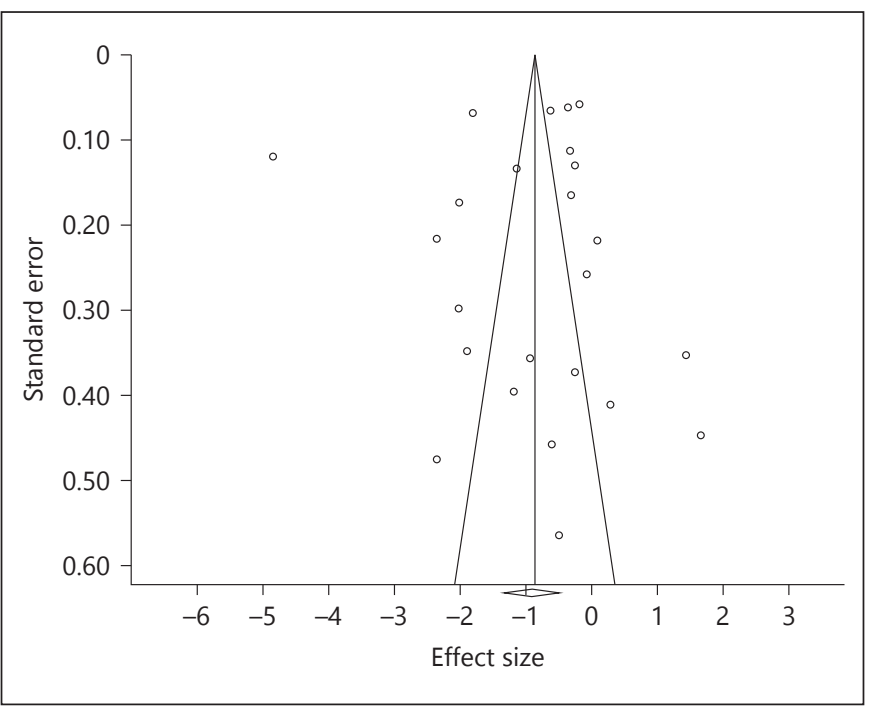

Fig. 3. Funnel plot of standard error of SMD $(d)$ against $(d)$ to assess for publication bias. SMD, standardized mean difference.

$\left.I^{2}=45.8 \%, p=0.158\right)$. The smallest effect was found for miscellaneous therapies with considerable heterogeneity $\left(\mathrm{SMD}=-0.03, p=0.947 ; I^{2}=91.6 \%, p<0.0001\right.$; Fig. 4$)$. In the GRADE quality assessment, pain severity was rated as moderate quality of evidence with respect to the need of more trials needed for certain subgroups to confirm the effect, such as for multidisciplinary team care and COMT inhibitors (Table 2).

\section{Sensitivity Analysis}

The first sensitivity analysis attempted to compensate for all missing participant data assuming the pain severity scores in control and treatment groups were the same. A -0.02-unit reduction in pain severity was seen in cannabinoids and opioids (SMD $=-2.26$ vs. SMD $=-2.24$ ), while a +0.02 -unit increase in pain severity was seen in pardoprunox $(S M D=-0.48$ vs. $S M D=-0.50)$. Surgery experienced a-0.01-unit decrease in pain severity $(\mathrm{SMD}=$ -0.43 vs. SMD $=-0.42)$. Effect sizes of all other groups did not change (Appendix 5).

To provide a more accurate and precise estimate of effect, a subsequent sensitivity analysis was conducted to exclude studies with high-risk bias concerns. Ten studies qualified for the secondary sensitivity analysis, of which 2 were dopaminergic agonists $[17,19], 1$ was part of the cannabinoids and opioids class [21], 3 among the electrical and Chinese therapies $[25,27,38]$, and 1 each for miscellaneous therapies [37], pardoprunox [30], safinamide [16], and COMT inhibitors [31]. Cannabinoids and opi- oids experienced a -0.02-unit reduction in pain severity $(\mathrm{SMD}=-2.26$ vs. $\mathrm{SMD}=-2.24)$, electrical and Chinese therapies displayed a -0.13 -unit reduction in pain severity $(\mathrm{SMD}=-1.11$ vs. $\mathrm{SMD}=-0.98)$, and a -0.12 -unit reduction in pain severity was seen for pardoprunox $(\mathrm{SMD}=-0.62$ vs. $\mathrm{SMD}=-0.50)$. Miscellaneous therapies experienced $\mathrm{a}+1.70$-unit increase in pain severity $(\mathrm{SMD}=$ +1.67 vs. $\mathrm{SMD}=-0.03)$. No changes to effect sizes were seen in any of the other groups (Appendix 5).

\section{Discussion}

According to the results, the most efficacious treatment is safinamide ( $\mathrm{SMD}=-4.83$ ), followed by cannabinoids and opioids ( $S M D=-2.30$ ). Safinamide is a selective, reversible monoamine-oxidase $\mathrm{B}$ inhibitor that reduces dopaminergic degradation and reuptake. This may make safinamide suitable for PD treatment during OFF periods, which occur as an end-of-dose worsening of the patient's response to levodopa [40]. However, it also has non-dopaminergic modes of action, including the state-dependent inhibition of voltage-gated sodium channels in the inactivated state and antiglutamatergic activity. These dopaminergic and non-dopaminergic actions may together account for its pain mitigating effects [16]. Numerous studies have shown that safinamide may be very effective at treating parkinsonian pain and is well tolerated in clinical trials [40-42]. Opioids act on opioid receptors and reduce neurotransmission. Cannabinoids control nociceptive thresholds via cannabinoid receptor agonism and may also affect tissues outside the nervous system. Both possess analgesic properties [43].

Multidisciplinary team care $(\mathrm{SMD}=-2.01)$, COMT inhibitors (SMD $=-1.81)$, and electrical and Chinese therapies (SMD $=-0.98$ ) were the next most effective. The COMT inhibitor trial pertained to entacapone, which inhibits the degradation of levodopa in the peripheral nervous system. Entacapone may therefore be effective in patients with musculoskeletal pain due to motor fluctuations or rigidity [44]. A multidisciplinary team intervention offers a comprehensive approach that may address numerous patient concerns in addition to pain, though it is unclear as to which parts of the team are the most important.

Miscellaneous therapies (SMD $=-0.03)$, dopaminergic agonists $(\mathrm{SMD}=-0.27)$, surgery $(\mathrm{SMD}=-0.42)$, and pardoprunox (SMD $=-0.48$ ) were the least effective. "Miscellaneous therapies" is an umbrella term for a 


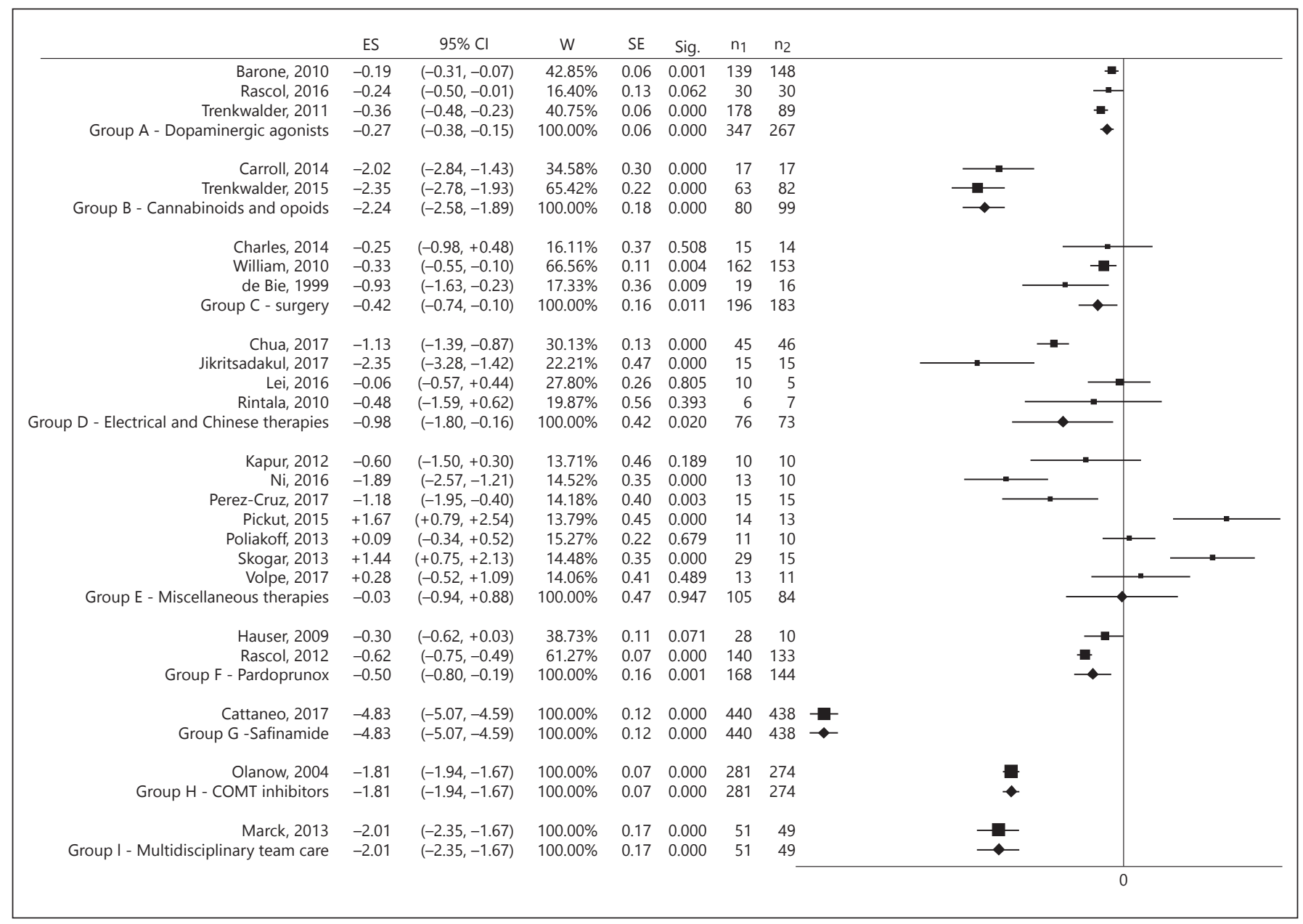

Fig. 4. A forest plot of the SMD $(d)$ of pain severity with PD therapy subgroups by indication*.* ES $=$ effect size $(\mathrm{SMD}-d)$; $\mathrm{W}$, weight; SE, standard error; $\mathrm{n}_{1}$, sample size for treatment; $\mathrm{n}_{2}$, sample size for control. SMD, standardized mean difference.

grouping of therapies that lack robust, evidence-based support for their efficacy. Interestingly, mindfulness therapy, gym training, massage therapy and hydrotherapy led to greater pain severity in treated participants compared to controls. This may have been attributable to poor methodological designs such as small sample size, or due to intervention-based exercise. Pardoprunox and other dopaminergic medications were not found to be very effective in reducing pain. This may suggest that pain in PD might not be explained solely by levels of dopamine. Our findings are supported by data from Buhmann et al. [4], who found that analgesics (including opioids) and rehabilitation (a multidisciplinary treatment) were highly effective at treating pain in $\mathrm{PD}$, while dopaminergic medications (unspecified which ones) were comparatively less effective.

Comprehensive Examination of Therapies for Pain in Parkinson's Disease
There are several limitations in our study. There was considerable heterogeneity in the trials included for Chinese and electrical therapies $\left(I^{2}=86.9 \%\right)$, as well as for miscellaneous therapies $\left(I^{2}=91.6 \%\right)$. In addition, some studies had significant loss-to-follow up rates, which may result in attrition bias. However, our first sensitivity analysis, which compensated for missing participant data $(n=511)$, found that effect sizes changed slightly or not at all, suggesting that attrition bias is unlikely to have changed our conclusions. Furthermore, some studies had ineffective blinding, small sample sizes, and notable methodological concerns such as the use of non-validated scales for pain measurement. However, our second sensitivity analysis, which accounted for bias-compromised studies, found that effect sizes were largely unchanged. There were only a few exceptions in 


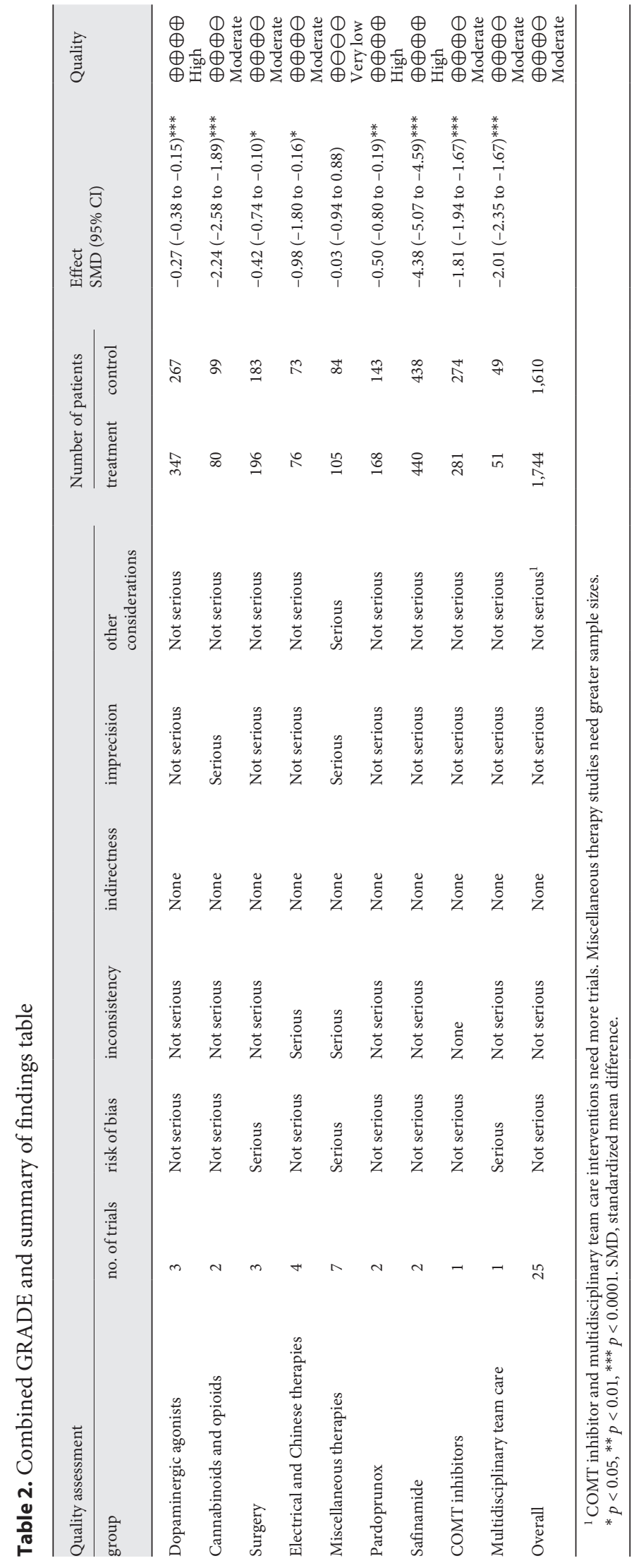

studies with weak efficacy, including a substantial increase in the miscellaneous therapies by a single mindfulness therapy study (SMD $=+1.67$ vs. SMD $=-0.03$ ). Studies with large effect sizes in pain severity did not experience changes in effect size, and hence our primary conclusions did not change. A notable limitation was that multiple subgroups such as multidisciplinary team care and COMT inhibitors were each composed of a single trial. Other subgroups such as cannabinoids and opioids, and surgery, or electrical and Chinese therapies had only 2, 3, or 4 studies, respectively. As our search was exhaustive, there is a clear paucity of RCT evidence relating to the aforementioned groups that included a measure of pain severity. Considering the Cochrane Collaboration recommends a minimum number of 10 studies in each subgroup for a subgroup effect to be considered believable [12], our results should be generalized cautiously.

\section{Implications for Clinical Practice and Research}

Our findings show that safinamide is an important adjunct to the standard parkinsonian medications for alleviating pain in $\mathrm{PD}$. Analgesics in the form of opioids and cannabinoids were shown to be effective but not nearly to the same extent. Thus, they are an important consideration if a patient responds poorly to safinamide. Although analgesic therapy is effective, only one-half of PD patients with pain report having used them [5, 45]. Nègre-Pagès et al. [45] found that analgesic use was lower for patients with $\mathrm{PD}$ pain as opposed to non-PD pain despite greater indices of pain severity and impairment of health-related quality of life. This may have arisen from the fact that PD pain was reported less frequently and/or because dopaminergic drug adjustment may have been preferred for PD pain treatment instead of analgesics. In light of our findings, it appears that dopaminergic drug adjustment yields little benefit, whereas adjusting levels of levodopa via entacapone (or presumably any other drug that inhibits peripheral metabolism of levodopa) may be a more favorable strategy. A multidisciplinary team approach is also recommended; however, additional studies with different team compositions need to be conducted to determine which teams work best. Furthermore, more trials of high methodological quality focusing on different aspects of pain (i.e., severity, temporality, localization, etc.) as well as the pathophysiological mechanisms of pain in PD are needed to form a consensus on the effectiveness of these therapies on patient-important outcomes related to pain. 


\section{Conclusion}

This systematic review and meta-analysis found that safinamide was the most efficacious among all studied therapies in reducing pain in PD. Cannabinoids and opioids, multidisciplinary team care, COMT inhibitors, and electrical and Chinese therapies all exhibited relatively lower, yet strong efficacy. Pardoprunox, surgery, and dopaminergic agonists had limited efficacy. Complementary therapies have little to no efficacy or in- crease rather than reduce pain in PD. More trials of high methodological quality focusing on different types of pain, as well as exploring novel therapies for pain in PD are warranted.

\section{Disclosure Statement}

The authors report no conflicts of interest. The authors received no funding of any form, or from any funding body for this manuscript.

\section{Appendix 1}

PRISMA Checklist

\begin{tabular}{|c|c|c|c|}
\hline Section/topic & Number & Checklist item & $\begin{array}{l}\text { Reported on } \\
\text { page number }\end{array}$ \\
\hline \multicolumn{4}{|l|}{ Title } \\
\hline Title & 1 & Identify the report as a systematic review, meta-analysis, or both & 1 \\
\hline \multicolumn{4}{|l|}{ Abstract } \\
\hline Structured summary & 2 & $\begin{array}{l}\text { Provide a structured summary including, as applicable: background; objectives; data } \\
\text { sources; study eligibility criteria, participants, and interventions; study appraisal and } \\
\text { synthesis methods; results; limitations; conclusions and implications of key findings; } \\
\text { systematic review registration number }\end{array}$ & 1 \\
\hline \multicolumn{4}{|l|}{ Introduction } \\
\hline Rationale & 3 & Describe the rationale for the review in the context of what is already known & $1-2$ \\
\hline Objectives & 4 & $\begin{array}{l}\text { Provide an explicit statement of questions being addressed with } \\
\text { reference to participants, interventions, comparisons, outcomes, } \\
\text { and study design (PICOS) }\end{array}$ & 2 \\
\hline \multicolumn{4}{|l|}{ Methods } \\
\hline $\begin{array}{l}\text { Protocol and } \\
\text { registration }\end{array}$ & 5 & $\begin{array}{l}\text { Indicate if a review protocol exists, if and where it can be accessed (e.g., Web } \\
\text { address), and, if available, provide registration information } \\
\text { including registration number }\end{array}$ & $\mathrm{N} / \mathrm{A}$ \\
\hline Eligibility criteria & 6 & $\begin{array}{l}\text { Specify study characteristics (e.g., PICOS, length of follow-up) and } \\
\text { report characteristics (e.g., years considered, language, publication } \\
\text { status) used as criteria for eligibility, giving rationale }\end{array}$ & 2 \\
\hline Information sources & 7 & $\begin{array}{l}\text { Describe all information sources (e.g., databases with dates of coverage, contact with } \\
\text { study authors to identify additional studies) in the search and date last searched }\end{array}$ & 2 \\
\hline Search & 8 & $\begin{array}{l}\text { Present full electronic search strategy for at least one database, including any limits } \\
\text { used, such that it could be repeated }\end{array}$ & $11-12$ \\
\hline Study selection & 9 & $\begin{array}{l}\text { State the process for selecting studies (i.e., screening, eligibility, included } \\
\text { in systematic review, and, if applicable, included in the meta-analysis) }\end{array}$ & 2 \\
\hline $\begin{array}{l}\text { Data collection } \\
\text { process }\end{array}$ & 10 & $\begin{array}{l}\text { Describe method of data extraction from reports (e.g., piloted forms, independently, } \\
\text { in duplicate) and any processes for obtaining and confirming data from investigators }\end{array}$ & 2 \\
\hline Data items & 11 & $\begin{array}{l}\text { List and define all variables for which data were sought (e.g., PICOS, } \\
\text { funding sources) and any assumptions and simplifications made }\end{array}$ & 2 \\
\hline $\begin{array}{l}\text { Risk of bias in } \\
\text { individual studies }\end{array}$ & 12 & $\begin{array}{l}\text { Describe methods used for assessing risk of bias of individual studies } \\
\text { (including specification of whether this was done at the study or outcome level), and } \\
\text { how this information is to be used in any data synthesis }\end{array}$ & 2 \\
\hline
\end{tabular}




\begin{tabular}{|c|c|c|c|}
\hline Section/topic & Number & Checklist item & $\begin{array}{l}\text { Reported on } \\
\text { page number }\end{array}$ \\
\hline Summary measures & 13 & State the principal summary measures (e.g., risk ratio, difference in means) & 2 \\
\hline Synthesis of results & 14 & $\begin{array}{l}\text { Describe the methods of handling data and combining results of studies, if done, } \\
\left.\text { including measures of consistency (e.g., } \mathrm{I}^{2}\right) \text { for each meta-analysis }\end{array}$ & 2 \\
\hline $\begin{array}{l}\text { Risk of bias across } \\
\text { studies }\end{array}$ & 15 & $\begin{array}{l}\text { Specify any assessment of risk of bias that may affect the cumulative evidence (e.g., } \\
\text { publication bias, selective reporting within studies) }\end{array}$ & 2 \\
\hline Additional analyses & 16 & $\begin{array}{l}\text { Describe methods of additional analyses (e.g., sensitivity or subgroup } \\
\text { analyses, meta-regression), if done, indicating which were pre-specified }\end{array}$ & 2 \\
\hline $\begin{array}{l}\text { Results } \\
\text { Study selection }\end{array}$ & 17 & $\begin{array}{l}\text { Give numbers of studies screened, assessed for eligibility, and included in the review, } \\
\text { with reasons for exclusions at each stage, ideally with a flow diagram }\end{array}$ & \\
\hline Study characteristics & 18 & $\begin{array}{l}\text { For each study, present characteristics for which data were extracted (e.g., study size, } \\
\text { PICOS, follow-up period) and provide the citations }\end{array}$ & $3,4-6,13-15$ \\
\hline $\begin{array}{l}\text { Risk of bias within } \\
\text { studies }\end{array}$ & 19 & $\begin{array}{l}\text { Present data on risk of bias of each study and, if available, any } \\
\text { outcome level assessment (see item 12) }\end{array}$ & 3,6 \\
\hline $\begin{array}{l}\text { Results of individual } \\
\text { studies }\end{array}$ & 20 & $\begin{array}{l}\text { For all outcomes considered (benefits or harms), present, for each study: } \\
\text { (a) simple summary data for each intervention group (b) effect estimates and } \\
\text { confidence intervals, ideally with a forest plot }\end{array}$ & $8,13-15$ \\
\hline Synthesis of results & 21 & $\begin{array}{l}\text { Present results of each meta-analysis done, including confidence intervals and } \\
\text { measures of consistency }\end{array}$ & $3,7,8$ \\
\hline $\begin{array}{l}\text { Risk of bias across } \\
\text { studies }\end{array}$ & 22 & Present results of any assessment of risk of bias across studies (see Item 15) & 7,9 \\
\hline Additional analysis & 23 & $\begin{array}{l}\text { Give results of additional analyses, if done (e.g., sensitivity or subgroup analyses, } \\
\text { meta-regression [see Item 16]) }\end{array}$ & 7,15 \\
\hline $\begin{array}{l}\text { Discussion } \\
\text { Summary of evidence }\end{array}$ & 24 & $\begin{array}{l}\text { Summarize the main findings including the strength of evidence for each main } \\
\text { outcome; consider their relevance to key groups (e.g., healthcare providers, users, } \\
\text { and policy makers) }\end{array}$ & $7-9$ \\
\hline Limitations & 25 & $\begin{array}{l}\text { Discuss limitations at study and outcome level (e.g., risk of bias), and at review-level } \\
\text { (e.g., incomplete retrieval of identified research, reporting bias) }\end{array}$ & 9 \\
\hline Conclusions & 26 & $\begin{array}{l}\text { Provide a general interpretation of the results in the context of other } \\
\text { evidence, and implications for future research }\end{array}$ & 10 \\
\hline
\end{tabular}

Funding

Funding
Describe sources of funding for the systematic review and other support (e.g., supply 10 of data); role of funders for the systematic review

\section{Appendix 2}

Search strategy. Conducted February 25, 2018.

\begin{tabular}{|c|c|c|c|c|}
\hline Medline & Embase & Cochrane & Cinahl & Psycinfo \\
\hline \#1. Pharmacotherap\$.mp or exp & \#1. Pharmacotherap\$.mp or exp & \#1. MeSH descriptor: [Pain & \#1. MH (“Parkinson’s disease”) & \#1. MJ Parkinson's disease \\
\hline Pharmacotherapy/ or Medical & Pharmacotherapy/ & treatment] explode all trees & OR MH ("Parkinson disease") OR & \#2. TX Pain \\
\hline therap\$.mp orexp Medical therapy/ & \#2. Medical therap\$.mp or exp & \#2. MeSH descriptor: & MH ("idiopathic Parkinson's & \#3. MJ Psychotherap* \\
\hline \#2. Drug therap\$,mp or exp Drug & Medical therapy/ & [Parkinson's disease] & disease") & \#4. MJ Cognitive \\
\hline therapy/ & \#3. Drug therap\$.mp or exp Drug & explode all trees & \#2. TX (“pain”) OR TX (“pain & behavio?ral therapy \\
\hline$\# 3.1$ or 2 & therapy/ & \#3. Parkinson's disease & severity") & \#5. MJ Behavio? ral therapy \\
\hline \#4. Dopamine agonist\$.mp or exp & $\# 4.1$ or 2 or 3 & \#4. Pain & \#3. (MH Pharmacotherapy) OR & \#6. MJ Gestalt therap* \\
\hline Dopamine agonists/ or MAO-B & \#5. Dopamine agonist\$.mp or exp & \#5. Pain severity & (MH Medical therapy) OR (MH & \#7. MJ Existential therap* \\
\hline
\end{tabular}




\begin{tabular}{|c|c|c|c|c|}
\hline Medline & Embase & Cochrane & Cinahl & Psycinfo \\
\hline $\begin{array}{l}\text { inhibitor\$.mp or exp MAO-B inhibitors } \\
\text { or COMT inhibitor\$.mp or exp COMT } \\
\text { inhibitors } \\
\text { \#5. Pramipexole.mp or Rotigotine.mpor } \\
\text { Transdermal patch.mp or Apomorphine. } \\
\text { mp or Ropinirole.mp or Pergolide.mp } \\
\text { or Bromocriptine.mp or Cabergoline.mp } \\
\text { or Amantadine.mp or selegiline.mp or } \\
\text { rasagiline.mp or safinamide.mp or } \\
\text { sumanirole.mp or piribedil.mp } \\
\text { \#6. Entacapone.mp or tolcapone.mp } \\
\text { \#7. Cannabis.mp or Cannabinoid\$.mp } \\
\text { or exp Cannabinoids/ or Opioid\$.mp or } \\
\text { exp Opioids/ } \\
\text { \#8. Anticholinergic } \$ . m p \text { or exp } \\
\text { Anticholinergics/ or } \\
\text { Trihexyphenidyl.mp } \\
\text { \#9. } 4 \text { or } 5 \text { or } 6 \text { or } 7 \text { or } 8 \\
\text { \#10 Psychotherap\$.mp or exp } \\
\text { Psychotherapy/ } \\
\text { \#11. (Cognitive or Behavio?ral or } \\
\text { Humanis } \$ \text { or Psychoanaly } \$ \text { or Holistic) } \\
\text { therap\$.mp } \\
\text { \#12. } 10 \text { or } 11 \\
\text { \#13. exp Physical therapy or } \\
\text { physiotherapy } \$ \text {.mp } \\
\text { \#14. exp (Complementary or } \\
\text { Alternative) medicine } \\
\text { \#15. (Exercise or massage or } \\
\text { mindfulness } \$ \text { ) therap\$.mp } \\
\text { \#16. Chinese medicine.mp or Herbal } \\
\text { treatment.mp } \\
\text { \#17. Chiropract } \$ . m p \text { or } \\
\text { Acupuncture.mp } \\
\text { \#18. Electr* therap\$.mp or Electric* } \\
\text { stimulat*.mp } \\
\text { \#19. } 13 \text { or } 14 \text { or } 15 \text { or } 16 \text { or } 17 \text { or } 18 \\
\text { \#20. Parkinson's disease.mp or } \\
\text { Parkinson disease.mp or exp } \\
\text { Parkinson's disease } \\
\text { \#21. Pain.mp or exp Pain } \\
\text { \#22. randomized controlled trial.pt. } \\
\text { \#23. controlled clinical trial.pt. } \\
\text { \#24. trial.ti. } \\
\text { \#25. placebo.ab. OR sham.ab. OR } \\
\text { standard.ab. } \\
\text { \#26. random*.ab } \\
\text { \#27. } 22 \text { or } 23 \text { or } 24 \text { or } 25 \text { or } 26 \\
\text { \#33. } 20 \text { and } 21 \text { and } 27 \\
\text { or } 12 \text { or } 19 \text { ) } \\
\text { \#35. Limit } 34 \text { to humans }\end{array}$ & 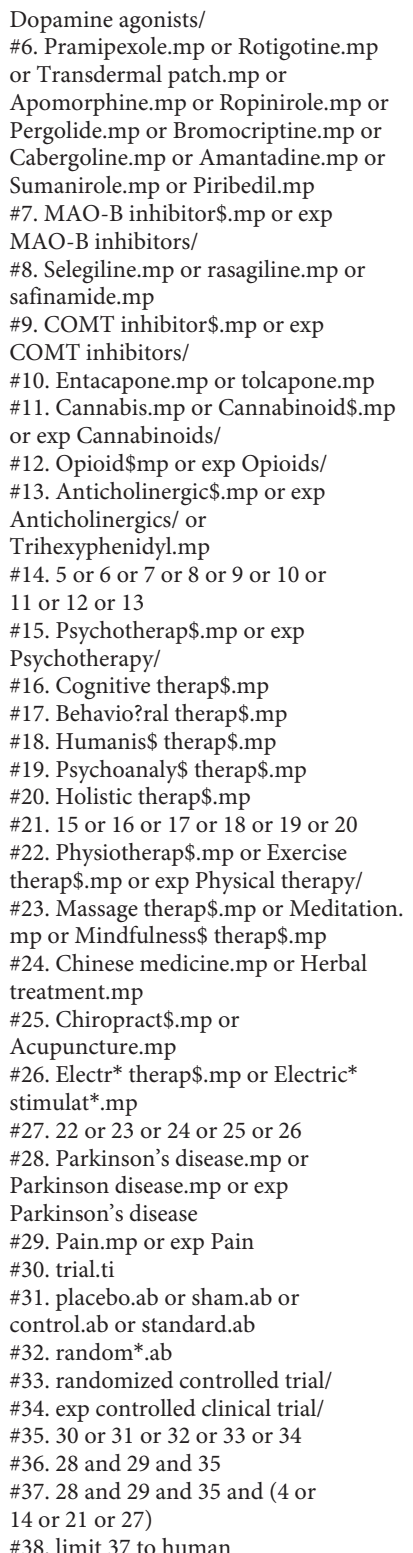 & $\begin{array}{l}\text { \#6. Pain score } \\
\text { \#7. Pharmacotherap\$ } \\
\text { \#8. Medical therap\$ } \\
\text { \#9. Physiotherap\$ } \\
\text { \#10. Psychotherap\$ } \\
\text { \#11. Deep brain stimulation } \\
\text { \#12. Surg\$ } \\
\text { \#13. Acupuncture } \\
\text { \#14. Massage therap\$ } \\
\text { \#15. Cognitive therap\$ } \\
\text { \#16. Exercise therap\$ } \\
\text { \#17. Holistic therap\$ } \\
\text { \#18. Psychotherap\$ } \\
\text { \#19. Multidisciplinary care } \\
\text { \#20. Chinese medicine } \\
\text { \#21. Herbal therap\$ } \\
\text { \#22. Transdermal patch } \\
\text { \#23. Cannabis } \\
\text { \#24. Marijuana } \\
\text { \#25. Rotigotine } \\
\text { \#26. Ropinirole } \\
\text { \#27. Sumanirole } \\
\text { \#28. Piribedil } \\
\text { \#29. Cannabinoid } \\
\text { \#30. Safinamide } \\
\text { \#31. Pardoprunox } \\
\text { \#32. Analges\$ } \\
\text { \#33. Selegiline } \\
\text { \#34. Rasagiline } \\
\text { \#35. Anticholinergic\$ } \\
\text { \#36. Amantadine } \\
\text { \#37. Apomorphine } \\
\text { \#38. Trihexyphenidyl } \\
\text { \#39. COMT* OR COMT } \\
\text { Inhibitors } \\
\text { \#40. Entacapone } \\
\text { \#41. Tolcapone } \\
\text { \#42. MAO-B Inhibitor } \\
\text { \#43. Electrical stimulation } \\
\text { \#44. Mindfulness\$ AND } \\
\text { therap\$ } \\
\text { \#45. Dopaminergic agonists } \\
\text { \#46. (\#7-\#42) AND \#3 AND \#4 } \\
\text { \#47. \#7-\#42) AND \#3 AND \#5 } \\
\text { \#48. (\#7-\#42) AND \#3 AND \#6 }\end{array}$ & $\begin{array}{l}\text { Drug therapy) } \\
\text { \#4. (MH Physiotherapy) OR (MH } \\
\text { Exercise therapy) OR (MH } \\
\text { Rehabilitation) } \\
\text { \#5. (MH Psychotherapy) OR (MH } \\
\text { Cognitive therapy) OR (MH } \\
\text { Behavio?ral therapy) OR (MH } \\
\text { Humanistic therapy) OR (MH } \\
\text { Psychoanalytic therapy) OR } \\
\text { (MH Holistic therapy) } \\
\text { \#6. (MH Acupuncture) OR (MH } \\
\text { Massage therapy) OR (MH } \\
\text { Electrical therapy) OR (MH } \\
\text { Electrical stimulation) } \\
\text { \#7. (MH Hydrotherapy) OR (MH } \\
\text { Water-based therapy) } \\
\text { \#8. (MH Deep brain stimulation) } \\
\text { OR (MH Subthalamic stimulation) } \\
\text { OR (MH Surgery) } \\
\text { \#9. (MH Multidisiplinary care) } \\
\text { OR (MH Allied health team care) } \\
\text { \#10. (MH Herbal medicine) OR } \\
\text { (MH Herbal therapy) OR (MH } \\
\text { Chinese medicine) } \\
\text { \#11. (MH cannabis) OR (MH } \\
\text { marijuana) OR (MH } \\
\text { cannabinoid*) } \\
\text { \#12. (MH opioid) } \\
\text { \#13. (MH rasagiline) OR (MH } \\
\text { selegiline) OR (MH MAO-B } \\
\text { inhibitor*) OR (MAO-B) } \\
\text { \#14. (MH COMT Inhibitor*) OR } \\
\text { (MH entacapone) OR (MH } \\
\text { tolcapone) } \\
\text { \#15. (MH safinamide) OR (MH } \\
\text { pardoprunox) OR (MH analges*) } \\
\text { \#16. (MH anticholinergic*) OR } \\
\text { (MH trihexyphenidyl) } \\
\text { \#17. (MH rotigotine) OR (MH } \\
\text { transderm* patch) OR (MH } \\
\text { pramipexole) OR (MH } \\
\text { apomorphine) OR OR (MH } \\
\text { sumanirole) OR (MH piribedil) } \\
\text { OR (MH Dopamin* agonist*) } \\
\text { \#18. (MH Randomized Controlled } \\
\text { Trial) OR (MH Controlled clinical } \\
\text { trial) OR (MH Controlled trial) OR } \\
\text { (MH Clinical trial) } \\
\text { \#19. (\#1) AND (\#2) AND (\#3-17) } \\
\text { AND (\#18) }\end{array}$ & $\begin{array}{l}\text { \#8. MJ Mindfulness-based } \\
\text { therap\$ } \\
\text { \#9. MJ Holistic therap* } \\
\text { \#10. MJ Yoga } \\
\text { \#11. MJ Humanistic therap* } \\
\text { \#12. MJ Client-centred } \\
\text { therap* } \\
\text { \#13. MJ Psychoanaly* } \\
\text { therap* OR Psychoanaly* } \\
\text { \#14. MJ Holistic therap* } \\
\text { \#15. MJ Meditation } \\
\text { \#16. MJ Randomized } \\
\text { controlled trial } \\
\text { \#17. MJ Controlled clinical } \\
\text { trial } \\
\text { \#18. \#1 AND \#2 AND (3 } \\
\text { OR } 4 \text { OR } 5 \text { OR } 6 \text { OR } 7 \text { OR } 8 \\
\text { OR 9 OR } 10 \text { OR 11 OR } 12 \\
\text { OR } 13 \text { OR } 14 \text { OR 15) AND } \\
\text { \#16 } \\
\text { \#19. \#1 AND \#2 AND (3 } \\
\text { OR } 4 \text { OR } 5 \text { OR 6 OR 7 OR } 8 \\
\text { OR 9 OR 10 OR 11 OR } 12 \\
\text { OR } 13 \text { OR } 14 \text { OR 15) AND } \\
\text { \#17 }\end{array}$ \\
\hline
\end{tabular}

\section{Appendix 3}

Group-wise summary of demographical characteristics*.

\begin{tabular}{|c|c|c|c|c|c|c|}
\hline \multirow[t]{2}{*}{ Group } & \multicolumn{2}{|c|}{ Age, years, mean (SD) } & \multicolumn{2}{|c|}{ Gender, Male, \% } & \multicolumn{2}{|c|}{$\begin{array}{l}\text { Disease duration, } \\
\text { years, mean (SD) }\end{array}$} \\
\hline & treatment & control & treatment & control & treatment & control \\
\hline A - Dopaminergic Agonists & $66.2(1.3)$ & $65.4(1.1)$ & 54 & 56 & $4.8(0.97)$ & $4.8(0.80)$ \\
\hline B - Cannabinoids \& Opioids & $66.9(0.2)$ & $67.2(0.4)$ & 56 & 59 & $10.5(5.0)$ & $10.4(5.2)$ \\
\hline C - Surgery & $59.8(0.68)$ & $60.1(1.2)$ & 68 & 70 & $14.0(2.8)$ & $14.4(4.8)$ \\
\hline
\end{tabular}




\begin{tabular}{|c|c|c|c|c|c|c|}
\hline \multirow[t]{2}{*}{ Group } & \multicolumn{2}{|c|}{ Age, years, mean (SD) } & \multicolumn{2}{|c|}{ Gender, Male, $\%$} & \multicolumn{2}{|c|}{$\begin{array}{l}\text { Disease duration, } \\
\text { years, mean }(\mathrm{SD})\end{array}$} \\
\hline & treatment & control & treatment & control & treatment & control \\
\hline D - Electrical \& Chinese Therapies & $67.9(5.5)$ & $68.2(5.3)$ & 61 & 59 & $8.9(4.2)$ & $5.6(0.67)$ \\
\hline E - Miscellaneous Therapies & $67.3(3.5)$ & $66.6(5.1)$ & 59 & 56 & $7.0(1.3)$ & $6.7(1.6)$ \\
\hline F - Pardoprunox & $63.6(1.7)$ & $63.6(2.1)$ & 67 & 61 & $7.1(0.57)$ & $6.6(0.0)$ \\
\hline I - Multidisciplinary Team Care & $65.9(8.5)$ & $68.1(8.8)$ & 59 & 57 & $4.6(3.9)$ & $3.7(3.5)$ \\
\hline
\end{tabular}

* Reported at base-line.

\section{Appendix 4}

Details of therapeutic intervention and control groups with standardized mean difference (d) and $95 \%$ confidence intervals for pain severity in the included trials.

\begin{tabular}{|c|c|c|c|c|c|c|c|}
\hline $\begin{array}{l}\text { First } \\
\text { author }\end{array}$ & Year & $\begin{array}{l}\text { Therapeutic } \\
\text { intervention }\end{array}$ & Treatment details & Control details & $\mathrm{d}(95 \% \mathrm{CI})$ & $\begin{array}{l}\text { Treatment } \\
\text { phase } \\
\text { duration, } \\
\text { weeks }\end{array}$ & $\begin{array}{l}\text { Follow-up } \\
\text { phase } \\
\text { duration, } \\
\text { weeks }\end{array}$ \\
\hline Barone [17] & 2010 & Pramipexole & $\begin{array}{l}\text { Titrated dosage } \\
\text { Increasing dose }(0.125 \mathrm{mg} / \text { day }-> \\
0.25 \mathrm{mg} / \text { day } \rightarrow 0.5 \mathrm{mg} / \text { day }->1.0 \mathrm{mg} / \text { day }) \\
\text { after every } 1 \text { week until antidepressant } \\
\text { effect achieved; max } 5 \text { weeks } \\
\text { Remaining } 7 \text { weeks: maintenance } \\
\text { treatment at one of above doses } 3 \times \text { day. } \\
\text { Tapered off for max. } 5 \text { days }\end{array}$ & $\begin{array}{l}\text { Identically appearing } \\
\text { placebo with same } \\
\text { procedure as shown in } \\
\text { treatment details }\end{array}$ & $-0.19(-0.31$ to -0.07$)$ & 12 & 2 \\
\hline Carroll [20] & 2004 & Cannabis & $\begin{array}{l}\text { Titrated dosage. } \\
\text { Body-weight dependent dose; max. } \\
0.25 \mathrm{mg} / \mathrm{kg} \text { THC, } 2 \times / \text { day }\end{array}$ & $\begin{array}{l}\text { Identically appearing } \\
\text { placebo capsules containing } \\
\text { synthetic oil vesicle, } 2 \times / \text { day }\end{array}$ & $-2.02(-2.60$ to -1.43$)$ & $\begin{array}{l}\text { 1) } 4 \\
\text { 2) } 4\end{array}$ & 2 \\
\hline Cattaneo [16] & 2017 & Safinamide & $100 \mathrm{mg} /$ day & $\begin{array}{l}\text { Identically appearing } \\
\text { placebo with same procedure } \\
\text { as shown in treatment details }\end{array}$ & $-4.83(-5.07$ to -4.59$)$ & 24 & $\begin{array}{l}\text { Study } 016: \\
18 \\
\text { SETTLE: } 4\end{array}$ \\
\hline Charles [22] & 2014 & $\begin{array}{l}\text { Deep brain } \\
\text { stimulation }\end{array}$ & $\begin{array}{l}\text { 24-month treatment phase } \\
\text { Receive bilateral subthalamic } \\
\text { nucleus stimulation AND } \\
\text { optimal drug therapy }\end{array}$ & $\begin{array}{l}\text { Drugs for standard PD care with } \\
\text { individualized regimens for } \\
\text { dosage, frequency and duration - ex- } \\
\text { amples: carbidopa/levodopa, prami- } \\
\text { pexole, ropinirole and } \\
\text { selegiline }\end{array}$ & $-0.25(-0.98$ to 0.48$)$ & $\begin{array}{l}\text { (Surgical } \\
\text { procedure) } \\
104\end{array}$ & $\begin{array}{l}\text { 1) } 52 \\
\text { 2) } 78 \\
\text { 3) } 104\end{array}$ \\
\hline $\begin{array}{l}\text { Chua } \\
{[25]}\end{array}$ & 2017 & Chinese medicine & $\begin{array}{l}\text { 32-week treatment phase } \\
\text { Active herbal treatment } 11 \mathrm{~g}, 2 \times / \text { day }\end{array}$ & $\begin{array}{l}\text { Identically appearing } \\
\text { placebo granules }\end{array}$ & $-1.13(-1.39$ to -0.87$)$ & 32 & 6 \\
\hline de Bie [24] & 1999 & $\begin{array}{l}\text { Unilateral } \\
\text { pallidotomy }\end{array}$ & $\begin{array}{l}\text { Receive surgical treatment } \\
\text { within } 1 \text { month } \\
\text { Assessment after } 6 \text { months }\end{array}$ & $\begin{array}{l}\text { Receive surgical treatment } \\
\text { after } 6 \text { months (delayed) }\end{array}$ & $-0.93(-1.63$ to -0.23$)$ & $\begin{array}{l}\text { Within } 4 \text { or } 5 \\
\text { (1 month) } \\
\text { (Surgical } \\
\text { procedure) }\end{array}$ & 26 \\
\hline Hauser [29] & 2009 & Pardoprunox & $\begin{array}{l}7 \text {-week treatment phase with } 1 \text { of } 2 \\
\text { titration schemes differentiated at day } 16 \text { : } \\
\text { Group } 1-6 \mathrm{mg} \text { /day increments } \\
\text { for } 7 \text { day each from } 6 \mathrm{mg} / \text { day start } \\
\text { to max. } 42 \mathrm{mg} / \text { day. Group } 2-6 \\
\mathrm{mg} / \text { day increments for } 3 \text { day each } \\
\text { from } 9 \mathrm{mg} / \text { day start to max. } \\
36 \mathrm{mg} / \text { day, THEN } 6 \mathrm{mg} / \text { day increments } \\
\text { for } 3 \text { day each from } 12 \mathrm{mg} / \text { day start } \\
\text { to max. } 42 \mathrm{mg} / \text { day. } 4 \text { days of } \\
\text { down-titration } 1 \text {-week follow-up }\end{array}$ & $\begin{array}{l}\text { Identically appearing placebo } \\
\text { with same procedure as in } \\
\text { treatment details }\end{array}$ & $-0.30(-0.62$ to 0.03$)$ & 7 & 1 \\
\hline
\end{tabular}




\begin{tabular}{|c|c|c|c|c|c|c|c|}
\hline $\begin{array}{l}\text { First } \\
\text { author }\end{array}$ & Year & $\begin{array}{l}\text { Therapeutic } \\
\text { intervention }\end{array}$ & Treatment details & Control details & $\mathrm{d}(95 \% \mathrm{CI})$ & $\begin{array}{l}\text { Treatment } \\
\text { phase } \\
\text { duration, } \\
\text { weeks }\end{array}$ & $\begin{array}{l}\text { Follow-up } \\
\text { phase } \\
\text { duration, } \\
\text { weeks }\end{array}$ \\
\hline $\begin{array}{l}\text { Jitkritsadakul } \\
\text { [26] }\end{array}$ & 2017 & Tremor's glove & $\begin{array}{l}\text { Resting hand-tremor suppressing medical } \\
\text { device comprised of an electrical muscle } \\
\text { stimulation (EMS) module and a tremor } \\
\text { detection module. } \\
\text { Sensor sampling rate is } 100 \mathrm{~Hz} / 10 \mathrm{~s} \\
\text { 30-min testing sessions for participants }\end{array}$ & $\begin{array}{l}\text { "Sham glove" - visually } \\
\text { identical and weight-wise } \\
\text { the same as the treatment, } \\
\text { except no EMS module }\end{array}$ & $-2.35(-3.28$ to -1.42$)$ & $\begin{array}{l}4 \text { or } 5 \\
(1 \text { month) }\end{array}$ & $\begin{array}{l}4 \text { or } 5 \\
(1 \text { month })\end{array}$ \\
\hline Kapur [38] & 2012 & $\begin{array}{l}\text { Vibration } \\
\text { therapy }\end{array}$ & $\begin{array}{l}\mathrm{CD} \text { player with a } 150 \mathrm{~W} \text { amplifier } \\
\text { connected to vibration transducers } \\
\text { on lounge chair mattress; } \mathrm{CD} \text { frequencies } \\
\text { ranged between } 30-500 \mathrm{~Hz} \text { for } 30 \mathrm{~min} / \text { day }\end{array}$ & $\begin{array}{l}\text { "No vibration" - CD player } \\
\text { disconnected from vibration } \\
\text { transducers }\end{array}$ & $-0.60(-1.50$ to 0.30$)$ & $\begin{array}{l}4 \text { or } 5 \\
\text { (1 month) }\end{array}$ & 1 day \\
\hline Lei [27] & 2016 & Electroacupuncture & $\begin{array}{l}\text { Scalp and body acupuncture with } \\
\text { electrical stimulation. } \\
\text { Electrical stimulation intensity } \\
\text { level = between } 3.5 \text { and } 4.5\end{array}$ & $\begin{array}{l}\text { Insertion of needles less than } 4 \mathrm{~mm} \\
\text { just under the skin at non-acupuncture } \\
\text { points (scalp, neck, shoulder, upper } \\
\text { and lower extremities); no needle } \\
\text { manipulation. } \\
\text { Electrical stimulation intensity } \\
\text { level =0 }\end{array}$ & $-0.06(-0.57$ to 0.44$)$ & 3 & 3 \\
\hline Marck [32] & 2013 & $\begin{array}{l}\text { Multidisciplinary } \\
\text { care }\end{array}$ & $\begin{array}{l}\text { Ongoing individualized care by } \\
\text { movement disorders specialist allied } \\
\text { with PD nurse and social worker }\end{array}$ & $\begin{array}{l}\text { Usual care provided by the } \\
\text { general neurologist }\end{array}$ & $-2.01(-2.35$ to -1.67$)$ & $\begin{array}{l}34.76 \\
\text { (8 months) }\end{array}$ & $\begin{array}{l}34.76 \\
\text { (8 months) }\end{array}$ \\
\hline $\mathrm{Ni}[39]$ & 2016 & Power yoga & $\begin{array}{l}\text { Progressively more challenging yoga } \\
\text { procedure of performing fast transition } \\
\text { of pose sequences, with each position } \\
\text { held for a maximum of } 3 \text { breaths }\end{array}$ & $\begin{array}{l}\text { Usual care from their general } \\
\text { neurologist + non-exercise health } \\
\text { education classes on changing your } \\
\text { lifestyle, pharmacotherapy, therapy and } \\
\text { exercise, nutrition and long-term care }\end{array}$ & $-1.89(-2.57$ to -1.21$)$ & $\begin{array}{l}13.03 \\
\text { (3 months) }\end{array}$ & Within 2 \\
\hline Olanow [31] & 2004 & Entacapone & $\begin{array}{l}200 \mathrm{mg} \text { for } 26 \text { weeks and gradually } \\
\text { withdrawn over } 2 \text { weeks }\end{array}$ & $\begin{array}{l}\text { Identically appearing placebo } \\
\text { with same procedure as shown in } \\
\text { treatment details }\end{array}$ & $-1.81(-1.94$ to -1.67$)$ & 28 & 2 \\
\hline $\begin{array}{l}\text { Perez de la } \\
\text { Cruz [33] }\end{array}$ & 2017 & Hydrotherapy & $\begin{array}{l}\text { A } 45 \text {-mine Aquatic Ai Chi program } \\
\text { comprised of } 19 \text { possible movements, } \\
\text { followed by a calming down activity }\end{array}$ & $\begin{array}{l}\text { 10-min Warm-up exercises, } \\
25 \text {-min strength training and aerobic } \\
\text { exercises, followed by a } 10 \text {-min } \\
\text { cooling down period }\end{array}$ & $-1.18(-1.95$ to -0.40$)$ & 10 & $\begin{array}{l}4 \text { or } 5 \\
(1 \text { month) }\end{array}$ \\
\hline Pickut [37] & 2015 & $\begin{array}{l}\text { Mindfulness } \\
\text { therapy }\end{array}$ & $\begin{array}{l}\text { A } 2.5 \text {-h session of meditation, yoga } \\
\text { and body scan closely following } \\
\text { mindfulness-based stress reduction }\end{array}$ & $\begin{array}{l}\text { Usual care from a movement } \\
\text { disorders specialist/neurologist when } \\
\text { needed }\end{array}$ & $1.67(0.79$ to 2.54$)$ & 8 & 8 \\
\hline Poliakoff [36] & 2013 & Gym training & $\begin{array}{l}\text { Biweekly program } \\
1 \text { h weekly training in studio - gait, agility, } \\
\text { some cardiovascular exercise and use of } \\
\text { external stimuli (e.g., music); teamwork } \\
\text { encouraged. } \\
1 \text { hour weekly training in gym - various } \\
\text { cardiovascular activities (e.g., treadmill) } \\
\text { emphasizing sustained physical activity }\end{array}$ & $\begin{array}{l}\text { Wait-listed to receive the same } \\
\text { program as the treatment group but } \\
\text { starting } 10 \text { weeks later }\end{array}$ & $0.09(-0.34$ to 0.52$)$ & 10 & 20 \\
\hline Rascol [30] & 2012 & Pardoprunox & $\begin{array}{l}\text { Titrated dosage } \\
\text { Starting dose individual-based, but end at } \\
12 \mathrm{mg} / \text { day by } 3 \text { weeks. } \\
\text { Between weeks } 3-7 \text { - individual dose } \\
\text { adjustments up to optimal maintenance } \\
\text { dose of } 42 \mathrm{mg} / \text { day }\end{array}$ & $\begin{array}{l}\text { Identically appearing placebo } \\
\text { following same titrating } \\
\text { procedure as the treatment }\end{array}$ & $-0.62(-0.75$ to -0.49$)$ & 7 & 1 \\
\hline Rascol [18] & 2016 & Rotigotine & $\begin{array}{l}\text { Transdermal patch } \\
\text { Titrated dose over } 1-7 \text { weeks starting } \\
\text { and incrementing by } 4 \mathrm{mg} / 24 \mathrm{~h} \text { and } \\
\text { incrementing until max. } 16 \mathrm{mg} / 24 \mathrm{~h} \text { reached }\end{array}$ & $\begin{array}{l}\text { Identically appearing placebo } \\
\text { patch with same titrating } \\
\text { regimen as the treatment }\end{array}$ & $-0.24(-0.50$ to 0.01$)$ & 7 & $\begin{array}{l}4 \\
(28 \text { days })\end{array}$ \\
\hline Rintala [28] & 2010 & $\begin{array}{l}\text { Cranial } \\
\text { electrotherapy }\end{array}$ & $\begin{array}{l}\text { Application of small amount of } \\
\text { electrical current ( } 100 \text { microamperes) } \\
\text { through the head via ear-clip electrodes } \\
\text { for } 40 \mathrm{~min} / \text { day }\end{array}$ & $\begin{array}{l}\text { Application of an identical } \\
\text { appearing and assembled sham device } \\
\text { that provided no electrical current } \\
\text { stimulation for } \\
40 \mathrm{~min} / \text { day }\end{array}$ & $e^{-0.48(-1.59 \text { to } 0.62)}$ & 6 & 6 \\
\hline Skogar [35] & 2013 & $\begin{array}{l}\text { Tactile } \\
\text { touch therapy }\end{array}$ & $\begin{array}{l}10 \text { sessions of Massage therapy using a } \\
\text { whole body tactile stimulation method }+ \\
\text { room immersed with lavender aroma }+ \\
\text { playing specific, destress-oriented music }\end{array}$ & $\begin{array}{l}\text { Specific destress-oriented music } \\
\text { played without the tactile } \\
\text { stimulation method }\end{array}$ & $1.44(0.75$ to 2.13$)$ & 11 & $\begin{array}{l}1.11 \\
2.14 \\
\text { 3. } 21 \\
4.34\end{array}$ \\
\hline
\end{tabular}




\begin{tabular}{|c|c|c|c|c|c|c|c|}
\hline $\begin{array}{l}\text { First } \\
\text { author }\end{array}$ & Year & $\begin{array}{l}\text { Therapeutic } \\
\text { intervention }\end{array}$ & Treatment details & Control details & $\mathrm{d}(95 \% \mathrm{CI})$ & $\begin{array}{l}\text { Treatment } \\
\text { phase } \\
\text { duration, } \\
\text { weeks }\end{array}$ & $\begin{array}{l}\text { Follow-up } \\
\text { phase } \\
\text { duration, } \\
\text { weeks }\end{array}$ \\
\hline $\begin{array}{l}\text { Trenkwalder } \\
{[19]}\end{array}$ & 2011 & Rotigotine & $\begin{array}{l}\text { Titrated dosage } \\
\text { Start: } 2 \mathrm{mg} / 24 \mathrm{~h} \text {, with } 2 \mathrm{mg} / 24 \mathrm{~h} \\
\text { increments to Max: } 16 \mathrm{mg} / 24 \mathrm{~h} \text {. } \\
\text { Max. dose maintained for } 4 \text {-weeks }\end{array}$ & $\begin{array}{l}\text { Identically appearing placebo } \\
\text { with same procedure as } \\
\text { shown in } \\
\text { treatment details }\end{array}$ & $-0.36(-0.48$ to 0.23$)$ & 12 & $\begin{array}{l}4 \text { or } 5 \\
\text { (1 month) }\end{array}$ \\
\hline $\begin{array}{l}\text { Trenkwalder } \\
{[21]}\end{array}$ & 2015 & $\begin{array}{l}\text { Oxycodone- } \\
\text { naloxone }\end{array}$ & $\begin{array}{l}\text { Oxycodone } 2 \times 5 \mathrm{mg} / 24 \mathrm{~h} \\
\text { Naloxone } 2 \times 2.5 \mathrm{mg} / 24 \mathrm{~h} \\
\text { Incremented only if pain not adequately } \\
\text { controlled } \\
\text { Max. Oxycodone: } 2 \times 20 \mathrm{mg} / 24 \mathrm{~h} \\
\text { Max. Naloxone: } 2 \times 10 \mathrm{mg} / 24 \mathrm{~h}\end{array}$ & $\begin{array}{l}\text { Identically appearing placebo } \\
\text { given } 2 \times / 24 \mathrm{~h}\end{array}$ & $-2.35(-2.78$ to -1.93$)$ & 16 & $\begin{array}{l}1-1.4 \\
(7-10 \text { days })\end{array}$ \\
\hline Volpe [34] & 2017 & Hydrotherapy & $\begin{array}{l}560 \text {-min sessions per week of a training } \\
\text { program for correcting posturaldeformities } \\
\text { within a therapeutic swimming pool }\end{array}$ & $\begin{array}{l}\text { Similar procedure as in } \\
\text { treatment, but non-water } \\
\text { based therapeutic environment }\end{array}$ & $0.28(-0.55$ to -0.10$)$ & 8 & $\begin{array}{l}8.69 \\
\text { ( } 2 \text { months) }\end{array}$ \\
\hline Williams [23] & 2010 & $\begin{array}{l}\text { Deep brain } \\
\text { stimulation }\end{array}$ & $\begin{array}{l}\text { Stimulation or lesioning of either the } \\
\text { subthalamic nucleus or globus pallidus } \\
\text { pars interna (Whichever is standard } \\
\text { during time of surgery) + Medical } \\
\text { therapy - } 10 \mathrm{mg} \text { apomorphine, dopaminc } \\
\text { agonists (e.g., } 3.3 \mathrm{mg} \text { rotigotine), MAO-B } \\
\text { inhibitors (e.g., } 10 \mathrm{mg} \text { selegiline), COMT } \\
\text { inhibitors (e.g., } 133 \mathrm{mg} \text { entacapone), } \\
100 \mathrm{mg} \text { amantadine, } 100 \mathrm{mg} \text { levodopa } \\
\text { and other PD-treating medications }\end{array}$ & Medical therapy only & $-0.33(-0.55$ to -0.10$)$ & $\begin{array}{l}\text { (Surgical } \\
\text { procedure) }\end{array}$ & $\begin{array}{l}52.14 \\
(1 \text { year) }\end{array}$ \\
\hline
\end{tabular}

\section{Appendix 5}

Sensitivity analysis of missing data and lower biased studies for the outcome of pain severity.

\begin{tabular}{|c|c|c|}
\hline Analysis type & Therapeutic intervention & SMD or overall SMD $(95 \% \mathrm{CI}), p$ value \\
\hline $\begin{array}{l}\text { Sensitivity analysis type I } \\
\text { Includes all patients enrolled in } \\
\text { the study, regardless of whether } \\
\text { they were successfully followed. } \\
(n=3,929)\end{array}$ & $\begin{array}{l}\text { Dopaminergic agonists } \\
\text { Cannabinoids and opioids } \\
\text { Surgery } \\
\text { Electrical and Chinese therapies } \\
\text { Miscellaneous therapies } \\
\text { Pardoprunox } \\
\text { Safinamide } \\
\text { COMT inhibitors } \\
\text { Multidisciplinary team care }\end{array}$ & $\begin{array}{l}-0.27(-0.27 \text { to }-0.38), p<0.0001 \\
-2.26(-2.56 \text { to }-1.95), p<0.0001 \\
-0.43(-0.76 \text { to }-0.09), p=0.012 \\
-0.98(-1.79 \text { to }-0.16), p=0.019 \\
-0.03(-0.91 \text { to } 0.85), p=0.947 \\
-0.48(-0.79 \text { to }-0.17), p=0.003 \\
-4.83(-5.05 \text { to }-4.61), p<0.0001 \\
-1.81 \text { ( }-1.92 \text { to }-1.69), p<0.0001 \\
-2.01 \text { ( }-2.32 \text { to }-1.70), p<0.0001\end{array}$ \\
\hline $\begin{array}{l}\text { Sensitivity analysis type II } \\
\text { Includes all studies with less than } \\
2 \text { high risk concerns on the risk } \\
\text { of bias assessment. } \\
(n=2,568)\end{array}$ & $\begin{array}{l}\text { Dopaminergic agonists } \\
\text { Cannabinoids and opioids } \\
\text { Electrical and Chinese therapies } \\
\text { Miscellaneous therapies } \\
\text { Pardoprunox } \\
\text { Safinamide } \\
\text { COMT inhibitors }\end{array}$ & $\begin{array}{l}-0.27(-0.43 \text { to }-0.11), p=0.001 \\
-2.35(-2.78 \text { to }-1.93), p<0.0001 \\
-1.11(-2.09 \text { to }-0.13), p=0.027 \\
1.67(0.79 \text { to } 2.54), p<0.0001 \\
-0.62(-0.75 \text { to }-0.49), p<0.0001 \\
-4.83(-5.07 \text { to }-4.59), p<0.0001 \\
-1.81(-1.94 \text { to }-1.67), p<0.0001\end{array}$ \\
\hline $\begin{array}{l}\text { Original analysis - complete case } \\
\text { analysis } \\
\text { Includes all patients who were } \\
\text { successfully followed. } \\
(n=3,354)\end{array}$ & $\begin{array}{l}\text { Dopaminergic agonists } \\
\text { Cannabinoids and opioids } \\
\text { Surgery } \\
\text { Electrical and Chinese therapies } \\
\text { Miscellaneous therapies } \\
\text { Pardoprunox } \\
\text { Safinamide } \\
\text { COMT inhibitors } \\
\text { Multidisciplinary team care }\end{array}$ & $\begin{array}{l}-0.27(-0.38 \text { to }-0.15), p<0.0001 \\
-2.24(-2.58 \text { to }-1.89), p<0.0001 \\
-0.42(-0.74 \text { to }-0.10), p=0.011 \\
-0.98(-1.80 \text { to }-0.16), p=0.020 \\
-0.03(-0.94 \text { to } 0.88), p=0.947 \\
-0.50 \text { ( }-0.80 \text { to }-0.19), p=0.001 \\
-4.83(-5.07 \text { to }-4.59), p<0.0001 \\
-1.81 \text { ( }-1.94 \text { to }-1.67), p<0.0001 \\
-2.01 \text { ( }-2.35 \text { to }-1.67), p<0.0001\end{array}$ \\
\hline
\end{tabular}




\section{References}

1 Rossi A, Berger K, Chen H, Leslie D, Mailman $\mathrm{RB}$, Huang X: Projection of the prevalence of Parkinson's disease in the coming decades: revisited. Mov Disord 2018;33:156-159.

2 Nussbaum RL, Ellis CE: Alzheimer's disease and Parkinson's disease. N Engl J Med 2003; 348:1356-1364.

3 De Lau LM, Breteler MM: Epidemiology of Parkinson's disease. Lancet Neurol 2006;5: 525-535.

4 Buhmann C, Wrobel N, Grashorn W, Fruendt O, Wesemann K, Diedrich S, Bingel U. Pain in Parkinson disease: a cross-sectional survey of its prevalence, specifics, and therapy. J Neurol 2017;264:758-769.

5 Broen MP, Braaksma MM, Patijn J, Weber WE: Prevalence of pain in Parkinson's disease: a systematic review using the modified QUADAS tool. Mov Disord 2012;27:480-484.

6 Beiske AG, Loge JH, Rønningen A, Svensson E: Pain in Parkinson's disease: prevalence and characteristics. Pain 2009;141:173-177.

7 Valkovic P, Minar M, Singliarova H, Harsany J, Hanakova M, Martinkova J, Benetin J: Pain in Parkinson's disease: a cross-sectional study of its prevalence, types, and relationship to depression and quality of life. PLoS One 2015; 10:e0136541.

8 Ehrt U, Larsen JP, Aarsland D: Pain and its relationship to depression in Parkinson disease. Am J Geriatr Psychiatry 2009;17:269275.

9 Martinez-Martin P, Rodriguez-Blazquez C, Kurtis MM, Chaudhuri K: The impact of nonmotor symptoms on health-related quality of life of patients with Parkinson's disease. Mov Disord 2011;26:399-406.

10 Chaudhuri KR, Healy DG, Schapira AH. Non-motor symptoms of Parkinson's disease: diagnosis and management. Lancet Neurol 2006;5:235-245.

11 Moher D, Liberati A, Tetzlaff J, Altman DG; PRISMA Group: Preferred reporting items for systematic reviews and meta-analyses: the PRISMA statement. PLoS Med 2009;6: e1000097.

12 Higgins JP. Green S: Cochrane handbook for systematic reviews of interventions version 5.1. 0 . The cochrane collaboration 2011;5.

13 Landis JR, Koch GG: The measurement of observer agreement for categorical data. Biometrics 1977;33:159-174.

14 DerSimonian R, Laird N: Meta-analysis in clinical trials. Control Clin Trials 1986;7:177188.

15 Atkins D, Best D, Briss PA, Eccles M, FalckYtter Y, Flottorp S, Guyatt GH, Harbour RT, Haugh MC, Henry D, Hill S. Grading quality of evidence and strength of recommendations. BMJ 2004;328:1490.

16 Cattaneo C, Barone P, Bonizzoni E, Sardina M: Effects of safinamide on pain in fluctuating Parkinson's disease patients: a post-hoc analysis. J Parkinsons Dis 2017;7:95-101.
17 Barone P, Poewe W, Albrecht S, Debieuvre C, Massey D, Rascol O, Tolosa E, Weintraub D. Pramipexole for the treatment of depressive symptoms in patients with Parkinson's disease: a randomised, double-blind, placebocontrolled trial. Lancet Neurol 2010;9:573580.

18 Rascol O, Zesiewicz T, Chaudhuri K, Asgharnejad M, Surmann E, Dohin E, Nilius S, Bauer L: A randomized controlled exploratory pilot study to evaluate the effect of rotigotine transdermal patch on Parkinson's disease-associated chronic pain. J Clin Pharmacol 2016;56:852-861.

19 Trenkwalder C, Kies B, Rudzinska M, Fine J, Nikl J, Honczarenko K, Dioszeghy P, Hill D, Anderson T, Myllyla V, Kassubek J: Rotigotine effects on early morning motor function and sleep in Parkinson's disease: a double-blind, randomized, placebo-controlled study (RECOVER). Mov Disord 2011;26: 90-99.

20 Carroll CB, Bain PG, Teare L, Liu X, Joint C, Wroath C, Parkin SG, Fox P, Wright D, Hobart J, Zajicek JP: Cannabis for dyskinesia in Parkinson disease: a randomized doubleblind crossover study. Neurology 2004;63: 1245-1250.

21 Trenkwalder C, Chaudhuri KR, MartinezMartin P, Rascol O, Ehret R, Vališ M, Sátori M, Krygowska-Wajs A, Marti MJ, Reimer K, Oksche A: Prolonged-release oxycodonenaloxone for treatment of severe pain in patients with Parkinson's disease (PANDA): a double-blind, randomised, placebo-controlled trial. Lancet Neurology 2015;14): 1161-1170.

22 Charles D, Konrad PE, Neimat JS, Molinari AL, Tramontana MG, Finder SG, Gill CE, Bliton MJ, Kao C, Phibbs FT, Hedera P: Subthalamic nucleus deep brain stimulation in early stage Parkinson's disease. Parkinsonism Relat Disord 2014;20:731-737.

23 Williams A, Gill S, Varma T, Jenkinson C, Quinn N, Mitchell R, Scott R, Ives N, Rick C, Daniels J, Patel S: Deep brain stimulation plus best medical therapy versus best medical therapy alone for advanced Parkinson's disease (PD SURG trial): a randomised, open-label trial. Lancet Neurol 2010;9:581-591.

24 De Bie RM, de Haan RJ, Nijssen PC, Rutgers AW, Beute GN, Bosch DA, Haaxma R, Schmand B, Schuurman PR, Staal MJ, Speelman JD: Unilateral pallidotomy in Parkinson's disease: a randomised, single-blind, multicentre trial. Lancet 1999;354:16651669.

25 Chua KK, Wong A, Chan KW, Lau YK, Bian ZX, Lu JH, Liu LF, Chen LL, Chan KH, Tse $\mathrm{KP}$, Chan A, et al: A randomized controlled trial of Chinese medicine on nonmotor symptoms in Parkinson's disease. Parkinsons Dis 2017;2017:1902708.

26 Jitkritsadakul O, Thanawattano C, Anan C, Bhidayasiri R: Tremor's glove-an innovative electrical muscle stimulation therapy for intractable tremor in Parkinson's disease: a randomized sham-controlled trial. J Neurol Sci 2017;381:331-340.

27 Lei H, Toosizadeh N, Schwenk M, Sherman S, Karp S, Sternberg E, Najafi B: A pilot clinical trial to objectively assess the efficacy of electroacupuncture on gait in patients with Parkinson's disease using body worn sensors. PLoS One 2016;11:e155613.

28 Rintala DH, Tan G, Willson P, Bryant MS, Lai EC: Feasibility of using cranial electrotherapy stimulation for pain in persons with Parkinson's disease. Parkinsons Dis 2010;2010: 569154.

29 Hauser RA, Bronzova J, Sampaio C, Lang AE, Rascol O, Theeuwes A, Van De Witte SV. Safety and tolerability of pardoprunox, a new partial dopamine agonist, in a randomized, controlled study of patients with advanced Parkinson's disease. Eur Neurol 2009;62:40-48.

30 Rascol O, Bronzova J, Hauser RA, Lang AE, Sampaio C, Theeuwes A, Van de Witte SV: Pardoprunox as adjunct therapy to levodopa in patients with Parkinson's disease experiencing motor fluctuations: results of a double-blind, randomized, placebo-controlled, trial. Parkinsonism Relat Disord 2012;18: 370-376

31 Olanow CW, Kieburtz K, Stern M, Watts R, Langston JW, Guarnieri M, Hubble J. Double-blind, placebo-controlled study of entacapone in levodopa-treated patients with stable Parkinson disease. Arch Neurol 2004;61: 1563-1568.

32 Marck MA, Bloem BR, Borm GF, Overeem S, Munneke M, Guttman M: Effectiveness of multidisciplinary care for Parkinson's disease: a randomized, controlled trial. Mov Disord 2013;28:605-611.

33 Pérez de la Cruz S: Effectiveness of aquatic therapy for the control of pain and increased functionality in people with Parkinson's disease: a randomized clinical trial. Eur J Phys Rehabil Med 2017;53:825-832.

34 Volpe D, Giantin MG, Manuela P, Filippetto C, Pelosin E, Abbruzzese G, Antonini A: Water-based vs. non-water-based physiotherapy for rehabilitation of postural deformities in Parkinson's disease: a randomized controlled pilot study. Clin Rehabil 2017;31:1107-1115.

35 Skogar Ö, Borg A, Larsson B, Robertsson L, Andersson L, Backstrom P, Fall PA, Hallgren G, Bringer B, Carlsson M, Lennartsson U: "Effects of Tactile Touch on pain, sleep and health related quality of life in Parkinson's disease with chronic pain": a randomized, controlled and prospective study. Eur J Integrat Med 2013;5:141-152.

36 Poliakoff E, Galpin AJ, McDonald K, Kellett M, Dick JP, Hayes S, Wearden AJ: The effect of gym training on multiple outcomes in Parkinson's disease: a pilot randomised waitinglist controlled trial. NeuroRehabilitation 2013;32:125-134. 
37 Pickut B, Vanneste S, Hirsch MA, Van Hecke W, Kerckhofs E, Mariën P, Parizel PM, Crosiers D, Cras P: Mindfulness training among individuals with Parkinson's disease: neurobehavioral effects. Parkinsons Dis 2015; 2015:816404.

38 Kapur SS, Stebbins GT, Goetz CG: Vibration therapy for Parkinson's disease: Charcot's studies revisited. J Parkinsons Dis 2012;2:2327.

39 Ni M, Mooney K, Signorile JF: Controlled pilot study of the effects of power yoga in Parkinson's disease. Complement Ther Med 2016;25:126-131.
40 Blair HA, Dhillon S: Safinamide: a review in parkinson's disease. CNS Drugs 2017;31:169176.

41 Schapira A, Fox S, Hauser R, Jankovic J, Jost W, Kulisevsky J, Pahwa R, Poewe W, Anand $\mathrm{R}$ : Safinamide add on to L-Dopa: a randomized, placebo-controlled, 24-week global trial in patients with Parkinson's disease (PD) and motor fluctuations (SETTLE)(P01. 062). Neurology 2013;80(7 Suppl):P01-062.

42 Borgohain R, Szasz J, Stanzione P, Meshram C, Bhatt MH, Chirilineau D, Stocchi F, Lucini V, Giuliani R, Forrest E, Rice P: Two-year, randomized, controlled study of safinamide as add-on to levodopa in mid to late Parkinson's disease. Mov Disord 2014;29:1273-1280.

43 Manzanares J, Julian MD, Carrascosa A: Role of the cannabinoid system in pain control and therapeutic implications for the management of acute and chronic pain episodes. Curr Neuropharmacol 2006;4:239-257.

44 Quinn NP, Lang AE, Koller WC, Marsden CD: Painful Parkinson's disease. Lancet 1986; 327:1366-1369.

45 Nègre-Pagès L, Regragui W, Bouhassira D, Grandjean H, Rascol O: Chronic pain in Parkinson's disease: the cross-sectional French DoPaMiP survey. Mov Disord 2008;23:1361-1369. 